\title{
CANINE RIB OSTEOSYNTHESIS BY REINFORCED ACRYLATE PLATE: A NEW SURGICAL METHOD FOR TREATING FLAIL CHEST
}

\author{
DONFRID B*, LOZANČE OLIVERA**, ALEKSIĆ-KOVAČEVIĆ SANJA** and TURINA M***
}

*Clinical Center Zvezdara, Belgrade, Serbia; **University of Belgrade, Faculty of Veterinary Medicine, Serbia; *** University Hospital, Zürich

(Received 12. April 2008)

Polymethylmetacrylate (PMMA) is an artificial resin that has a wide application in a number of medical disciplines, surgery included. The use of acrylate is limited due to its modest mechanical features. Hence in this study, as an "in vivo" experiment on dogs, the usefulness of "reinforced acrylate" in the form of armored acrylate plates in the surgery of fractured ribs in flail chest has been valued.

In earlier studies we have shown that polymethylmetacrylate, when reinforced with non-alkaline glass fibers, has improved mechanical characteristics (bending, stretching and crash resistance) compared with not reinforced, or in any other way strengthened acrylate.

In this study the value of armored acrylate plates (AAP) in the sanation of flail chest in dogs has been verified, as well as its good biological tolerability as a new implant material in dogs. An original approach to surgical reposition and osteosynthesis of fractured ribs in dogs has been determined. An innovative approach to rib osteosynthesis with acrylate plates can be an adequate model for its application in human patients with unstable flail chest, which is often the result of injury or tumor excision.

Key words: dog, flail chest, rib osteosynthesis, polymethylmetacrylate, non-alkaline glass fibers.

\section{INTRODUCTION}

Flail chest is one of the most serious chest injuries which have as the pathoanatomical substrate double or multiple serial rib fractures, while its pathophysiological root is described by paradoxal breathing (Kirsh and Sloan 1977; Glinz, 1978).

Flail chest therapy is dependant upon the extensiveness of the injury, type of flail, concurrent trauma of chest organs and injuries of other organ systems (Kirndoerfer et al., 1980; Kovačević and Donfrid, 1989). Many suggestions have been made with regard to the best course of treatment. Some of these have been over time through surgical praxis over-ridden, but still many persist and are in 
parallel use, as surgeons are still searching for the perfect method (Boetsch and Rehm, 1981; Bühren and Trenz, 2005). They can be classified as conservative or surgical methods. Among conservative methods the most common are: local and systemic analgesia, bandage immobilization (cingulum), adhesive tape immobilization (hemicingulum), intercostal blocks (Aubart, 1979), epidural thoracic analgesia (Jonhston and McCaughey, 1980), extension with skin pincers, subcutaneous and subcostal wire loops, external fixators (Pan, 1993). In the group of surgical rib osteosynthesis methods the most commonly used are: pericostal stitches (Kessler, 1978), transthoracal wire stitches (Albreht and Brug, 1979), transmedullar osteosynthesis with wire needles (Moore, 1975), internal vertical fixation with Kirschner intermedullary nails (Di Fabio et al., 1995), metal plates and wire thoracic cerclage (Oyarzun et al., 1998), metal plates with screws (Bevilacqua et al., 1977), self supporting plates (Judet, 1973; Labitzke, 1981), plates with spikes (Vescei et al., 1979) and compressive osteosynthesis with metal plates (AO) (Hellberg et al., 1981; Reber et al., 1993). For the internal stabilization of flail chest synthetic plastic materials are used, as well. They are applied in different shapes and forms, such as: absorbing plates (Mayberry et al., 2003) and nonabsorbent synthetic resins (Glavaš et al., 2001).

The introduction of assisted respiration in chest trauma has improved the overall results of treatment (Avery et al., 1956). Internal pneumatic fixation with a respirator has resulted in a revolutionary decrease in death casualties in the course of treatment of chest trauma. However, during its prolonged use the ventilator has shown a number of setbacks such as: mechanical damage of the lung parenchyma, infections, thrombosis due to relaxation and decubital changes on the trachea (Voggenreiter et al., 1998). Due to the aforementioned, modern authors tend to fix the chest wall as soon as possible and reduce the time of intubation as a method of internal pneumatic fixation to its minimal required time (Donfrid and Kovačević, 1985; Lardinois et al., 2001; Tanaka et al., 2002).

As there is no ideal or by doctrine accepted therapy treatment of flail chest, in this study the aim was set on dogs as experimental animals in order to apply a new surgical approach to fix unstable flail chest. A stable osteosynthesis was achieved by an "ex tempore" constructed fixative apparatus which matched the morphological characteristics of the ribs, and thus developed the starting point for a new surgical approach applicative for chest trauma in human medicine (Donfrid, 2000).

\section{MATERIAL AND METHODS}

In order to determine the possibility for the application of reinforced polymethylmetacrylate armored with glass fibers on human patients we carried out a study on dogs which are considered adequate experimental animals for this purpose. The experiment was created as two distinctive trials: four dogs as an example of acute patients and six dogs as chronic cases. In the acute trial the most appropriate mode of inducing (under total anesthesia) rib fractures was studied and carried out as three ribs were fractured in two lines, thus flail chest was created. Subsequently the most effective surgical reposition was performed 
Donfrid B et al.: Canine rib osteosynthesis by reinforced acrylate plate:

a new surgical method for treating flail chest

and the fixation of the fragments carried out "ex tempore" with the aid of pre-cast acrylate plates. An original press for modeling and reinforcing the acrylate paste was constructed for the purpose of this trial.

After gaining surgical experience on the acute model a procedure for chronic patients in the experiment was agreed upon. The adopted procedure consisted of the following steps: the quarantined dogs were premedicated and thereof transferred in the surgery room equipped with an imaging X-ray apparatus. The dogs underwent endotracheal anesthesia and were set in the left recumbent position. In the right hemithoracal region the hair was removed and the surgical field disinfected as required by standard surgical procedures. With the aid of a diatherm by circular incision starting from the sternum at the level of the sixth rib, down to the fifth, sixth and seventh rib the skin and muscle tissue were prepared. In two stages, 6-7 cm apart, the ribs above the endothoracical fascia were cut by a Gillis' seesaw in such a fashion that the costal pleura was left intact. Thus, we constructed an experimental flail chest (Figure 1).

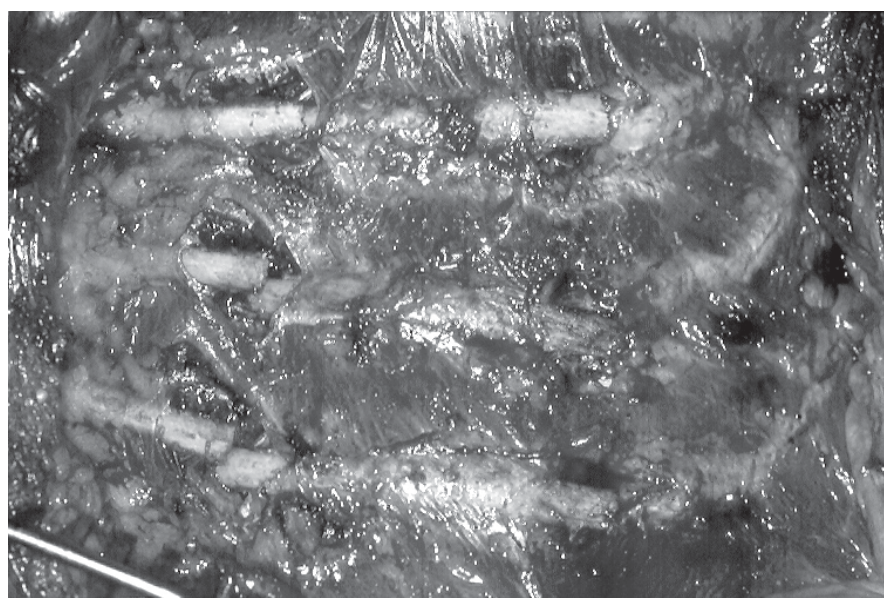

Figure 1. Dog, experimental flail chest

The chronic experiment was carried out on a total of 6 mongrel dogs, from 3 to 5 years of age and body mass from 25 to $30 \mathrm{~kg}$. Before and after surgery blood samples were taken for routine analysis (hematology, electrolytes, biochemistry and enzymes). The animals were kept for $90-136$ days and underwent once again the surgical procedure in order to check out the outcome of osteosynthesis and sampling of bone tissue for subsequent studies. The animals were than humanely euthanized by an i.v. injection of $7.45 \% \mathrm{KCl}$.

During the surgical procedure the standard vital functions parameters were monitored, as well as blood gas analyses. 
Chest X-ray imaging was done after the first surgery (in order to check the pleural space, the reposition and osteosynthesis of the ribs) and after the second operation performed in order to remove the acrylate plates.

For pathohistological analysis the following tissues were sampled: heart, lung, kidney, adrenal gland, connective tissue close to the ribs, and rib bone callus close to the site of experimental fractures. Tissue samples were fixed in $10 \%$ buffered formalin. They were processed automatically and embedded in paraffin. Following usual rehydration procedures, slices 3-6 $\mu \mathrm{m}$ thick were stained by hematoxylin-eosin and Giemsa procedures. Analysis of stained histological samples and digital photo documentation were done on Olympus Bx41 microscope.

The experiment was performed in University Hospital in Zürich (Switzerland) and Faculty of Veterinary Medicine (Belgrade, Serbia), in accordance to EU Directive 86/609 and the Bologna Declaration (1999) on animal welfare.

\section{RESULTS AND DISCUSSION}

The results of our study, the surgical procedures and the technique of acrylate plate modeling are reported in the following details.

The adopted surgical and modeling technique: rib fragments were fixed with an atraumatic wire suture commonly applied for sternotomy closure. With the tip of the needle the periost was closely followed in order to avoid injuries of the pleura, intercostal blood vessels, and nerves. The so placed wire loops were than fixed with pincers, and by retraction the rib fragments were set in an ideal reposition.

In a plastic container an adequate amount of methylmetacrylate monomer was poured (Palacos liquid) and the polymer (Palacos powder) was added up to the point of saturation. The dough is vigorously stirred until it stopped sticking to the sides of the container. The width of the mold in the press is adjusted according to the size of the previously measured ribs. A piece of fiber glass cloth is cut accordingly. Over the press is than placed a plastic sheath which prevents sticking of the polymethylmetacrylate to the walls of the mold and with a spatula a layer of Palacos is spread over the surface (Figure 2). Thereof, the glass fiber cloth is set and a second layer spread on (Figure 3). The mold is set in the press and squeezed until all the air bubbles and excess cast is pushed out. In such a way we have obtained a model of the desired shape and size. The plate was than taken out of the mold together with the plastic sheath, while the acrylate mass is still in a plastic state. Modeling of the polymer is possible during the following 3-4 minutes which is sufficient to adapt the plate to the prepared rib.

Acrylate polymerization is accompanied by release of heat. Thermal tissue damage is prevented by pouring cold saline over the plate. Once it gains rigidity it can be separated from the rib. The cast plate is than set back on the rib surface and fixed with previously placed wire loops (one ligature per fragment) (Figure 4). The chest wall is than closed in the standard manner, with no drainage (Figure 5).

Biocompatibility: as it can be seen from the obtained results, besides a precisely established surgical procedure and check ups of respiratory function 
Acta Veterinaria (Beograd), Vol. 59. No. 1, 81-90, 2009.

Donfrid B et al.: Canine rib osteosynthesis by reinforced acrylate plate:

a new surgical method for treating flail chest

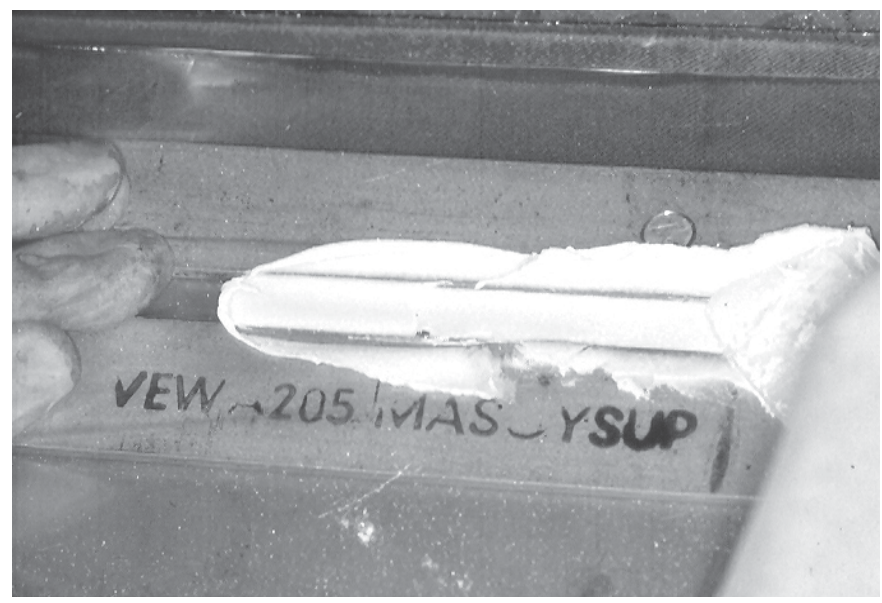

Figure 2. PMMA moulding

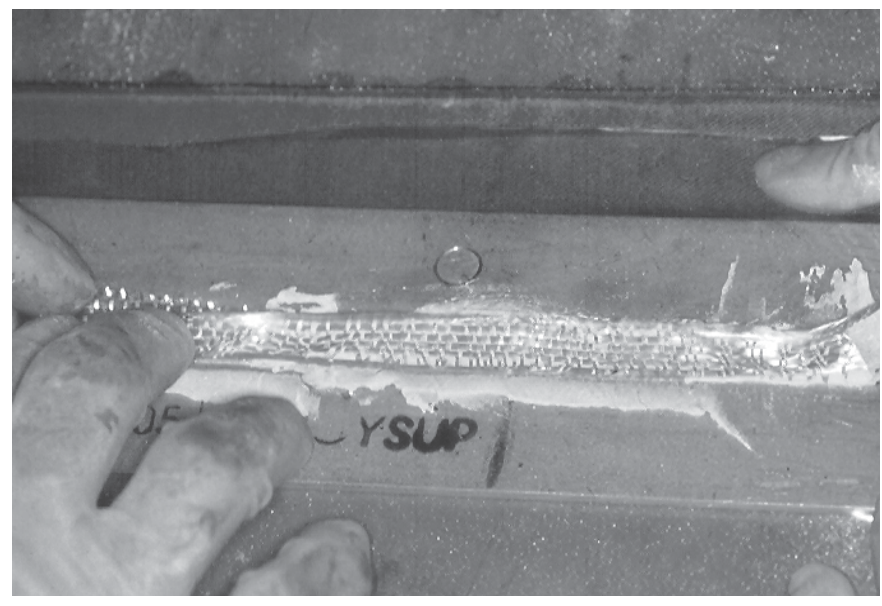

Figure 3. PMMA reinforcing

over a period of 90 to 136 days, the studied tolerance of dogs to the implanted material has shown that not in one case pathological values were recorded (Donfrid, 2000). Imaging diagnostic procedures, such as $\mathrm{x}$-ray radiography at the beginning and end of the trial had proven a complete chest reconstruction (Figure $6 \mathrm{a}, \mathrm{b}$ ). Pathohystology of the tissue samples (heart, lungs, liver, spleen, kidney and adrenal glands) not in a single patient have displayed negative effects of the implant on the aforementioned organs. Studies carried out on rib bone marrow tissue on the places of the healed fractures (Figure $7 \mathrm{a}, \mathrm{b}, \mathrm{c}, \mathrm{d}$ ) and soft tissues close to the acrylate plates did not show any changes which could be considered 


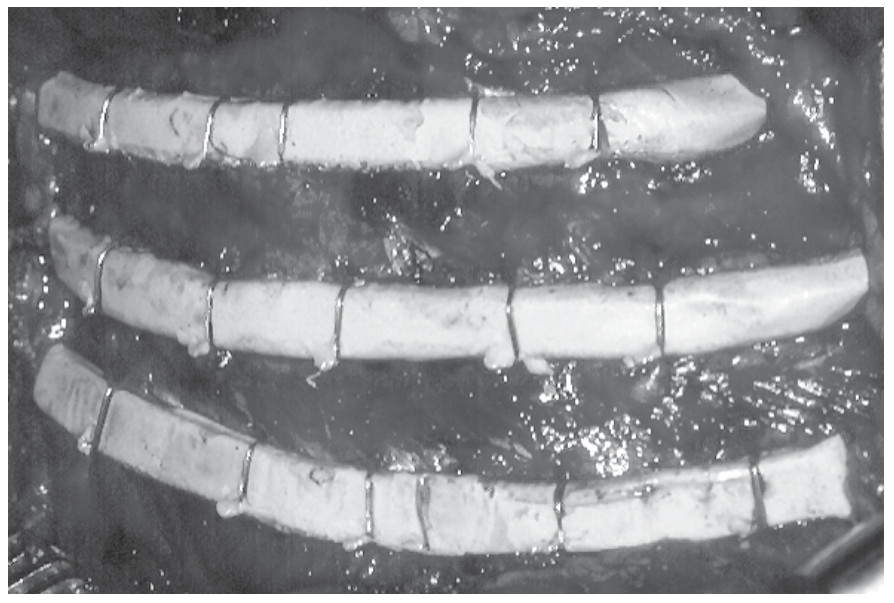

Figure 4. PMMA plates in situ

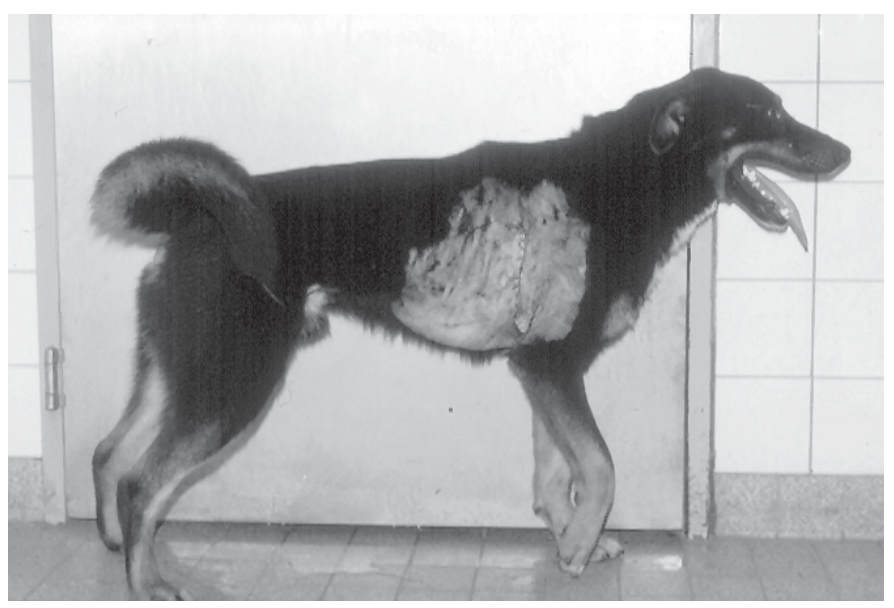

Figure 5. Dog, after rib osteosynthesis

pathological. Thus, we can consider that the used acrylate plates represent a very good choice of material to be used for implants.

Polymethylmetacrylate both as a synthetic material for prosthesis fixation and a surgical implant material has shown excellent biocompatibility (Charnley, 1972). Its more widespread application is limited by its modest mechanical characteristics, specially its weakness during bending. Among the first published studies relative to the improvement of the mechanical characteristics of acrylates used in medicine the trials on reinforcement by metal supporting wires (Usova 1955; Mišić, 1968) or fortification of wire mashing by acrylate resins (Tysvaer and 
Acta Veterinaria (Beograd), Vol. 59. No. 1, 81-90, 2009.

Donfrid $\mathrm{B}$ et al.: CAnine rib osteosynthesis by reinforced acrylate plate:

a new surgical method for treating flail chest
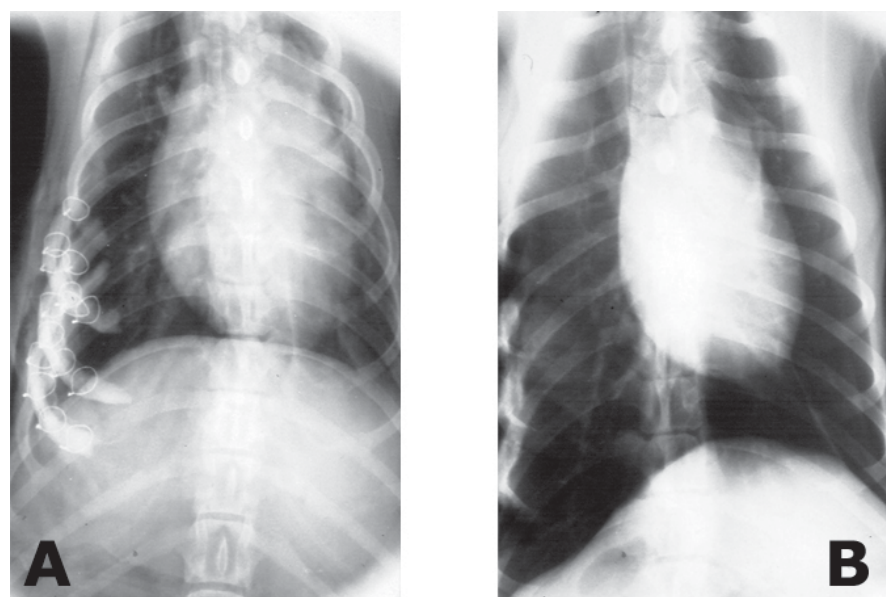

Figure 6. a) Dog, chest X-ray after rib osteosynthesis

b) Dog, chest X-ray at the end of experiment
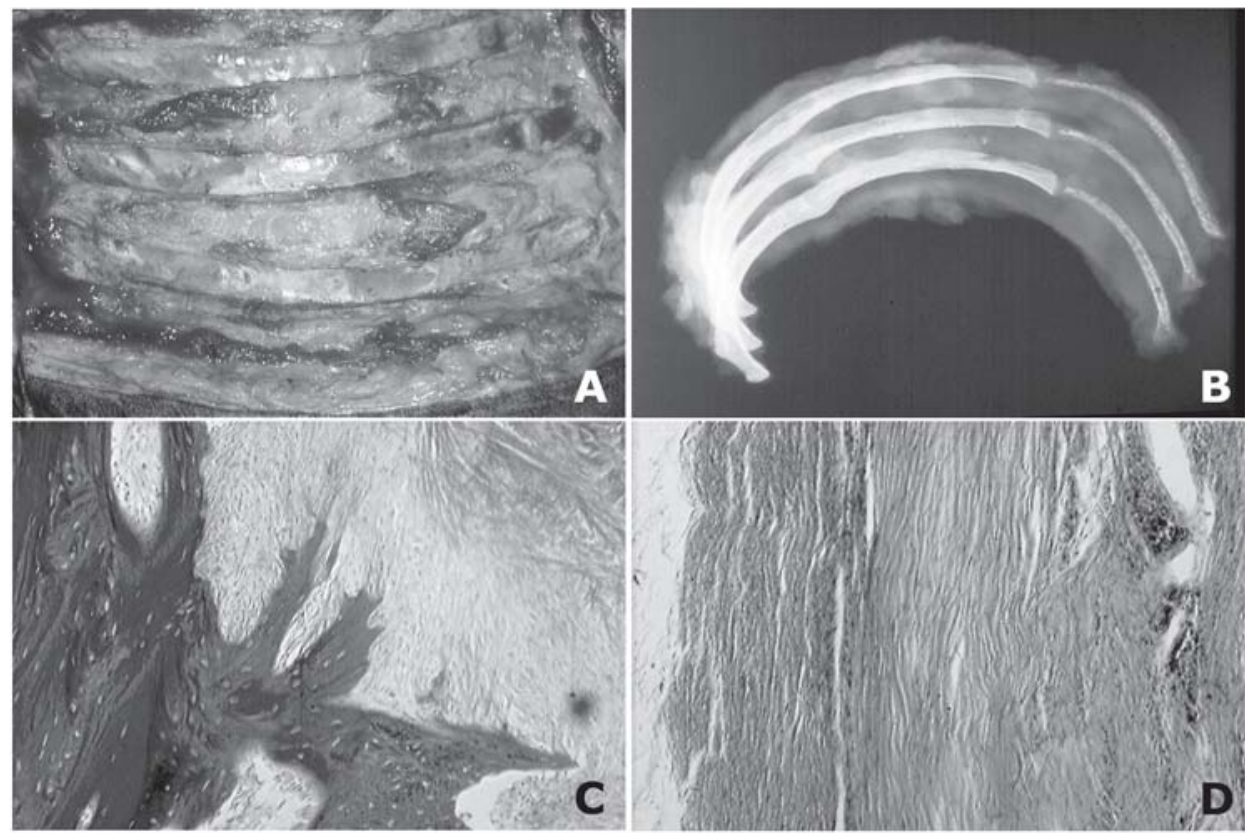

Figure 7. a) Dog, chest wall after plate explantation; b) Dog, X-ray of healed ribs;

c) Dog, rib bone calus; HE, $100 \mathrm{x}$; d) Dog, surrounding fibrous tissue, $200 \mathrm{x}$

Hovind, 1977) are the most innovative. Despite various attempts to fortify acrylates with other synthetic materials such as: polypropylene (Marlex) (Herriot and Wells 
1977), polyester (Mersilen) (Kilic et al., 2006), carbon fibers (Woo et al., 1974) the achieved improvements were insignificant and the process too troublesome for everyday practice.

Our first efforts to strengthen the polymethylmetacrylate with not alkaline glass fibers for dental prosthesis have shown promising results. These models were constructed at the Clinic for Prosthetics at the Faculty of Dental Medicine in Belgrade, and the mechanical tests were preformed at the Institute for Construction Materials in Belgrade (Donfrid, 1980). The application of strengthened acrylate has been suggested for the manufacturing of missing limbs prosthesis, maxillofacial traumatology, cranioplastic surgery, osteoplastic interventions on long and small bones (Donfrid, 1971; 1980; Donfrid and Kovačević, 1984).

The results of this study show the applicative value of strengthened acrylate plates for rib osteosynthesis in the course of flail chest therapy. The theoretical biocompatibility of the used materials had been proved. As no previous findings relative to the subject have been found in the available literature, this paper can be considered to by an original contribution.

\title{
ACKNOWLEDGMENT:
}

This paper was supported by grant 156010 from the Ministry of Science of the Republic of Serbia.

\author{
Address for correspondence: \\ Branislav Donfrid, MD, PhD \\ Clinical Center Zvezdara, Belgrade \\ Dimitrija Tucovića 161 \\ 11000 Belgrade \\ Serbia \\ E-mail: branislav.donfrid@gmail.com
}

\section{REFERENCES}

1. Albreht VF, Brug E, 1979, Die Zuggurtungsosteosynthese der Rippen und des - Sternuims bei instabiler Thoraxwand, Zb/ Chirurgie, 104, 770-6.

2. Aubart $F$, 1979, Fractures de cotes et leur traitment, Revue de I Infirmiere, 29, 59-62.

3. Avery EE, Morch ET, Benson DW, 1956, Critically crushed chest: A new method of tretment with continuous mechanical hyperventilation to produce alcalotic apnea and internal pneumatic stabilization, J Torac Surg, 32, 291-311.

4. Bevilacqua G, Sinigaglia M, Staudacher V, 1977, Technique chirurgicale originale pour le traitment du volet thoracique mobile, $J$ Chir Paris, 114, 4, 293-8.

5. Boetsch H, Rehm KE, 1981, Biomechanische Untersuchungen an Rippenosteosynthesen, Biomedizinische technik, 26, 296-301.

6. Bühren V, Trenz O, 2005, Checkliste Traumatologie, Georg Thieme Verlag, Stuttgard - New York, 223-41.

7. Charnley J, 1972, Acrylic Cement in Orthopedic Surgery, Churchill-Livingstone, Edinburgh and London, 1-124.

8. Declaration of Bologna, 1999, Reduction, Refinement and Replacement Alternatives and Laboratory Animal Procedures, 3rd World Congress on Alternatives and Animal Use in the Life Sciences, Bologna, Italy.

9. Di Fabio D, Benetti D, Benvenuti M, Mombelloni G, 1995, Surgical stabilization of post-traumatic flail chest. Our expiriens with 116 cases treated, Minerva Chir, 50, 3, 227-33. 
10. Directive $86 / 609$ EEC of 24 November 1986 on the approximation of laws, regulations and administrative provisions of the Member States regarding the protection of animals used for experimental and other scientific purposes. Official Journal of the European Communities 1986, L358, 1-29.

11. Donfrid B, 1970, Pokušaj ojačavanja akrilata staklenim vlaknima, XII stručni kongres studenata medicine i stomatologije Jugoslavije, Beograd, Knjiga rezimea, 17-18.

12. Donfrid B, 1971, Ispitivanje upotrebne vrednosti armiranog polimetilmetakrilata za intramedularnu oseteosintezu, XIII stručni kongres studenata medicine i stomatologije Jugoslavije, Sarajevo, Knjiga rezimea, 34

13. Donfrid B, 1980, Armirani akrilat kao osteosintetski i implantacioni materijal u traumatologiji i rekonstruktivnoj hirurgiji, XV kongres hirurga Jugoslavije, Ljubljana, Sažeci, 426.

14. Donfrid B, Kovačević S, 1984, Osteosinteza rebara akrilatnom pločicom u eksperimentu na usmrćenima u uslovima realne torakalne traume i politraume, XVI kongres kirurga Jugoslavije, Zagreb, Zbornik radova, I deo, 57.

15. Donfrid B, Kovačević S, 1985, Nestabilni grudni koš-kliničko forenzički aspekt, Drugi naučni sastanak saobraćajne medicine, Zbornik radova, Zemun-Beograd, 372-6.

16. Donfrid $B, 2000$, Evaluation of reinforced acrylate in treatment of flail chest in blunt chest trauma, PhD thesis, Medical Faculty, Belgrade.

17. Glavaš M, Altarac S, Vukas D, Ivančić A, Dražinić I, Gusić N et al., 2001, Flail chest stabilization with palacos prosthesis, Acta Med Croatica, 55, 2, 91-5.

18. Glinz W, 1978, Torax-Verletzungen, Diagnose, Beurteilung und Behandlung, Springer-Verlag, Berlin Heidelberg New York, 97-118.

19. Hellberg K, de Vivie ER, Fuchs K, Heisig B, Ruschewski W, Luhr HG et al., 1981, Stabilization of flail chest by compression ostheosynthesis-experimental and clinical results, Thotrac Cardiovasc Surgeon, 29, 275-81.

20. Heriot AG, Wells FC, 1997, An unsual case od flail chest:surgical repair using Marlex mesh, Thorax, 52, 5, 488-9.

21. Johnston JR and McCaughey W, 1980, Epidural morphine-a method of managament of multiple fractured ribs, Anaesthesia, 35, 155-7.

22. Judet R, 1973, Osteosynthese costale, Rev Chir Orthop, 59, 334-5.

23. Kessler E, 1978, New aspects in operative flail chest management, Thorax Chir Vas Chir, 26, 4, 280-

24. Kilic D, Gungor A, Kavukcu S, Okten I, Ozdemir N, Akal M et al., 2006, Comparison of Mersilen Mesh - methylmetacrylate sandwitch and polytetrafluoroethylen grafts for chest wall reconstruction, $J$ Invest Surg, 19, 6, 353-60.

25. Kirndoerfer D, Filler D, Muhrer KH, 1980, Das Throaxtrauma, Zbl Chirurgie, 105, 209-19.

26. Kirsh MM, Sloan H, 1977, Blunt chest trauma, general principles of management, Little, Brown and Company, Boston, 81-105.

27. Kovačević $S$, Donfrid $B$, 1989, Kliničko forenzička dijagnostika povreda grudnog koša u saobraćajnim nesrećama, Povrede grudnog koša, Zavod za udžbenike i nastavna sredstva, Beograd, 87-91.

28. Labitzke R, 1981, Die Bedeutung der Thoracotomie und Brustwandstabilisirung mit Rippenklammern im Bechandlungkonzept des Thoraxtraumas, Zb/ Chirurgie, 106, 1351-9.

29. Lardinois D, Krueger T, Dusmet M, Ghisletta N, Gugger M, Ris HB, 2001, Pulmonary function testing after operative stabilisation of the chest wall for flail chest, Eur J Cardiothorac Surg, 20, 3, 496501.

30. Mayberry JC,Terhes JT, Ellis TJ, Wanek Sandra, Mullins RJ, 2003, Absorable plates for rib fracture repair: preliminary expiriense, $J$ Trauma Inj Inf Crit Care, 55, 5, 835-9.

31. Mišić B, 1968, Ispitivanje vrednosti polimetilmetakrilata u osteosintezi femura psa, Acta Veterinaria, 18, 3, 165-74

32. Moore BP, 1975, Operative stabilization of non-penetrating chest trauma, $J$ Thorac Cardiovasc Surg, 70, 619-30 
33. Oyarzun JR, Bush AP, McCormick JR, Bolanowski PJ, 1998, Use of 3.5-mm acetabula reconstruction plates for internal fixation of flail chest injuries, Ann Thorac Surg, 65, 5, 1471-4.

34. Pan GE, 1993, Use of a portable sternal rib traction fixator in the tretment of flail chest, Zhonghua Hu Li Za Zhi, 28, 1, 598-600.

35. Reber P, Ris HB, Inderbitzi R, Stark B, Nachbur B, 1993, Osteosynthesis of the injured chest wall. Use of the AO technic, Scand J Thorac Cardiovasc Sur, 27, 3-4,137-42.

36. Tanaka H, Yukoioka T, Yamaguti Y, Shimizu S, Goto H, Matsuda H et al., 2002, Surgicals stabilization of internal pneumatic stabilization. A prospective randomized study of management of severe flail chest patients, J Trauma-Injury Infect Criti Care, 52, 4, 727-32.

37. Tysvaer AT, Hovind KH, 1977, Stainless steel mesh-acrylic cranioplasty, J Trauma, 17, 3, 231-3.

38. Usova MM, 1955, Osteosynthesis of Fractures with metal-plastmass construction, Vesth Khir Im II Grek, 75, 5, 37-44.

39. Vescei V, Frenzel J, Plenk HJr, 1979, Eine neue Rippenplatte zur Stabilisierung, Unfallheilkunde, 138, 279-82.

40. Voggenreiter G, Neudeck F, Aufmkolk M, Obertacke U, Schmit-Neuerburg KP, 1998, Operative chest wall stabilization in flail chest-outcomes of patients with or without pulmonary contusion, $\mathrm{J} A m$ Col Sur, 187, 2, 130-8.

41. Woo SL-Y, Akerson WH, Levenetz B, Coutts RD, Matthews JV, AmileI D, 1974, Potential application of graphite fiber and methyl metacrylate resin composites as internal fixation plates, $J$ Biomed Mater Res, 8, 323-38

\title{
OSTEOSINTEZA REBARA PASA ARMIRANOM AKRILATNOM PLOČICOM: ORIGINALNA HIRURŠKA METODA U LEČENJU TORAKALNOG KAPKA
}

\author{
DONFRID B, LOZANČE OLIVERA, ALEKSIĆ-KOVAČEVIĆ SANJA i TURINA M
}

\section{SADRŽAJ}

Polimetilmetakrilat (PMMA) je veštačka smola koja je našla široku primenu u brojnim medicinskim oblastima, uključujući i hirurgiju. Kako je primena akrilata ograničena njegovim relativno slabim mehaničkim osobinama, u ovom radu je u "in vivo" eksperimentu na psima ispitana upotrebna vrednost "ojačanog akrilata" odnosno armirane akrilatne pločice u hirurškom lečenju preloma rebara kod nestabilnog zida grudnog koša (torakalnog kapka).

Našim ranijim istraživanjima dokazali smo da polimetilmetakrilat armiran bezalkalnim staklenim vlaknima poseduje znatno bolja mehanička svojstva (jačinu na savijanje, istezanje i udar) od nearmiranog ili na neki drugi način ojačanog akrilata.

U ovom radu je u ogledima na psima dokazana vrednost armirane akrilatne pločice (AAP) u lečenju torakalnog kapka i potvrđena dobra biološka podnošljivost AAP kao implantnog materijala. Utvrđen je originalni postupak hirurške repozicije i osteosinteze prelomljenih rebara, a usvojena originalna tehnika osteosinteze rebara akrilatnom pločicom kod pasa može da bude adekvatan model postupka za primenu kod ljudi sa nestabilnim zidom grudnog koša, kao posledice teških povreda ili defekta zida toraksa prilikom ekscizije tumora. 